\title{
Transition Pathways to Sustainable Pastoral Systems in Europe
}

\author{
Rafael Caballero*
}

Instituto de Ciencias Agrarias (CSIC). Finca Experimental la Poveda. Ctra. de Campo Real km 1. 28500 Arganda del Rey. Madrid, Spain

\begin{abstract}
Large Scale Grazing Systems (LSGSs) in Europe are extensive systems of grassland management, which have developed from the interaction of historical background, human behaviour and natural resources, and are mainly located in the Less Favoured Areas (LFAs). LSGSs currently face competing threats towards intensification and/or abandonment but, at the same time, they harbour a significant part of European nature values. Socio-economic driving forces of land abandonment and intensification are poorly addressed. The current system assumes that these LSGSs are inherently uneconomic and only payments for the potential delivery of environmental services and side line activities are the source of continuity and justification of support. Our conceptual approach, however, is based on the assumptions that endogenous development and targeted policy schemes cannot be disregarded. A framework profile is provided for the identification and description of European LSGSs where regeneration plans can be more cost-effective. Under this conceptual approach, operational tools such as pastoral strategies for survival and system-specific management alternatives can be devised for interplay of environmental and socio-economic functions, facilitating interdisciplinary research within and across systems. From the empirical perspective, we show how the trend of abandonment of LSGS in the last 60 years is spread over different regions of Europe, how management alternatives are designed for six separate LSGS, and how beneficial management alternatives, environmental functions and side line activities cited by experts on an additional sample of 46 European LSGS are grouped by type of action. We conclude that the continuity of LSGSs in the European Union (EU) may require a new and sustainable intensification path with new farming models and farming categories as far removed from the conventional intensification path as from the low-input, nature reserve and generalised policy support paradigms. Beneficial management with key actions can be a sensible rationale for specific and dynamic support to LSGS in the next CAP reform post-2013, time of stressing budgetary conditions.
\end{abstract}

Keywords: Cultural landscapes, farming abandonment, grazing management alternatives, high nature value (HNV) farmland, large scale grazing systems (LSGS), policy framework, sustainable intensification, territorial identity.

\section{INTRODUCTION}

The Less Favoured Areas (LFA) in the rural environment of the European Union (EU) are designated in the legal documents of the European Commission (EC) as those environmentally handicaps areas (climate or topography) regarding land productivity potential and thus justifying some scheme of agricultural support. In the most recent revamping of the Common Agricultural Policy (CAP), support to LFA has been coupled with agri-environment schemes in the second Pillar of the CAP. In Spain, Total Agricultural Land (TAL), takes up some $90-95 \%$ of the country area and around $80 \%$ of TAL was rated as LFA under EC criteria.

In recent decades, changes in cultural landscapes of Europe, and particularly in the Less Favoured Areas (LFAs), have taken place at unprecedented scale and speed [1]. Typical concerns are land use abandonment and/or intensification of land use and loss of regionally-specific forms of agricultural production. These changes are having an impact on

*Address correspondence to this author at the Instituto de Ciencias Agrarias (CSIC). Finca Experimental la Poveda. Ctra. de Campo Real km 1. 28500 Arganda del Rey. Madrid, Spain; E-mail: rcaballero@ica.csic.es cultural and environmental values [2] and their resilience capacity can be at risk. Large areas of pastureland in the LFAs of Europe are being abandoned or in the process of being unused, but the precise scale, speed and underlying causes is poorly researched.

There is much interest in researching and rehabilitation of these marginal areas but their heterogeneity requires to set a main land use category that can be the subject of environmental and socioeconomic analysis. As much of the LFA marginal areas are occupied by some type of pastoral systems, we have chosen the extensive systems of grassland managements or Large Scale Grazing Systems (LSGS) as the spatial units for social-ecological analysis all across Europe with particular emphasis in Spain.

We will focus this research on the scientific analysis of change in a wide range of extensive pastoral systems, and how social and ecological criteria can be integrated in support of sustainable change and shape up of public policy. On a global range of European social and ecological setting we may distinguish three types of LSGS on their transition pathway. On the most developed and populated regions of central and Western Europe (an Atlantic arch from France to Denmark), the traditional LSGS are mostly a relic of the 
past. In the marginal and mountainous regions of Mediterranean countries such as Spain, Italy or Greece, LSGS are still operative but sustainable transition pathways blurred and the LSGS under a general downwards trend. Its general features are less mobile systems, more indoor feeding operations, less use of indigenous breeds and far-reaching grazing grounds abandoned. Only in the less developed European regions of SE Europe LSGS are still largely operating under traditional ways but insecurity for continuation given the lack of interest by young farmers. There is a need on comparative analysis as to whether we may find sustainable paths of change in pursuit of maintaining social and environmental assets of LSGS.

In Europe, transition models in pastoral societies and systems are focussed on the intensification-extensification debate as two contrasting threats, and land abandonment is considered the most extreme form of extensification [3-5]. The low-input systems [6-8], the rationale of delivering public goods to justify the use of financial incentives [9], and the uncongenial inter-disciplinary approach [10] are common paradigms today. Traditional definition of low-input restricts the use of conventional (capital, labour or technology) but also of less-conventional (social empowerment, cultural knowledge, formal and informal institutions) production factors in support of agricultural change. Under a conceptually inaccessible hypothesis, bringing together researchers of different ethos and disciplines around LSGSs' case studies that have "little in common" may only produce mixed effects. In other words, inter-systems and interdisciplinary research is hard to carried out and giving positive effects. A more recent strategy assumes that strengthening direct links with nature may empower traditional farming communities to embrace sustainable development [11].

Here we argue that the changes in the European pastoral systems of the marginal areas cannot be look in a logic that merely oppose an extreme form of extensification (land abandonment) to a form of conventional intensification (saving labour and increasing external inputs). A new form of intensification is required to sustain these systems and their land assets.

In the international literature intensification can take many forms (capital, labour, technological improvements or institutional reforms) and aims. Also the international literature doest not mention restrictions on capital and labour but also stress these systems as encapsulating cultural knowledge and traditions, formal and informal social institutions and indigenous products. Adaptive forms of management would require the use of capital and labour without this type of support being intrinsically unsustainable [12, 13]. Many pastoral societies and traditional livestock systems are in need of inputs to implement pastoral surviving strategies and alternative management practices as adaptation to global economic environment [14]. This would require in-depth and community-based knowledge of systems as a combination of nature and human components with particular functions. Only after this, can management alternatives be devised and implemented in pursuit of sustainable development. Under our sustainable intensification paradigm, we hypothesize that Europeans LSGS in very different bioregions may share constraints and resilient proposals in the form of beneficial management alternatives.

European LSGS may have much in common than supposed, and economic, environmental and social synergies cannot be disregarded. Under our main approach, social cohesion and continuity of LSGS operations at the European scale requires an endogenous and expert-like prospective incursion over a wide range of environments and a policy rationale derived from the empirical results. The most recent schemes of support and wishful plight to strength farmers' link to nature values have showed mixed effects.

This research is aimed at providing a conceptual framework of pastoral system changes and empirical evidence from which policy rationale and legal proposals of publiclyfunded EU support for marginal areas can be derived. The main objective is to design an alternative transition path to sustainable development for pastoral systems located in the LFAs of the EU. Here we argue that in these marginal areas, the real debate should not be between intensification and extensification, but between exclusion (a fossilised or relic state and left-to-their-own prospect) and rehabilitation (a dynamic and working landscape).

Three main parts can be appreciated in this paper. First, we define and developed the use of the scientific concepts and knowledge with respect to change in pastoral systems including a framework profile with the main attributes of LSGS. In the second part, we apply these concepts and tools to get empirical evidence in an extensive sample of LSGS and comparative study areas across a wide range of European environmental conditions. This sampling included six study areas of the LACOPE project [15] with on-farming records, and additional European sample of 46 study areas with experts' records all linked to different European bioregions. A more in depth analysis of additional 14 Spanish LSGS is available elsewhere [2]. The third part will be mainly a derivative of the previous concepts and analysis entailing sections on biodiversity values, socioeconomic status and the policy relevance of the comparative analysis.

\section{CONCEPTUAL FRAMEWORK}

\section{Framework Profile of LSGSs}

The scope of the paper in searching for sustainable path of change for European pastoral systems requires the definition of the unit of analysis at the landscape scale. Definition of LSGS aim at characterising the dynamic relationships between grazing systems, vegetation changes and plant and animals biodiversity, which are considered relevant to sustainable livestock systems at landscape scale from agronomic, ecological and socio-economic perspectives. Traditional LSGS are complex structures emerging from the interaction of historical background, human behaviour and natural resources in the Less Favoured Areas [16]. In short, LSGS are a substantial part of European cultural landscapes in need of planning and management tools for rehabilitation and continuity. According to these aims, LSGS can be defined by a profile framework encompassing some distinctive features: 
LSGS are identified within the boundaries of biogeographical regions in Europe [17]. This setting allows for identification of natural or semi-natural vegetation types and plant and animal species' distribution as related in the EU Habitat Directive [18], which use the same geographical stratification [19]. This common link takes into account determinants of history, geology, geography and climate. It also represents a proper spatial scale for study of the relationships between grazing use and natural values [2]. Map 1 depicts our large sample of European LSGS on their corresponding environmental zones with location and dominant livestock grazer. Discrimination and distribution of nature values across European LSGS can be the base for a costeffective planning of environmental conservation [20, 21]. Management conservation and policy support can be planned as LSGS can be related to vegetation cover types included in the EU Habitat Directive and land use types of EU statistics. Livestock farmers and their grazers manage and use grazing land vegetation types included in the EU habitat Directive and thus, management and support are allocated to farmers not to vegetation types. A substantial part of these vegetation types and their associated rare or endangered species depend on grazing use.

LSGS are land based systems in the sense that spatial and temporal distribution of grazing resources has some effect on grazing management of animals' lots. The large landscape scale allows for avoiding overgrazing in most of the area, and for relating biodiversity values to this spatial scale [22].

LSGS have an historical background and are culturallyrooted in a social endeavour, with specific institutional setting including formal and informal institutions [23], social values [24] and stakeholders interactions [20]. As this setting fostered actual values and concerns, human intervention cannot be disregarded in transition models to sustainable pastoral systems. In short, LSGS are a substantial part of European cultural landscapes as it addresses the role of social systems in the dynamics of pastoral systems and the landscape.

LSGS farmers have developed distinctive pastoral strategies for survival regarding land use and grazing management. Mobility of herds/flocks, accessibility to potential grazing resources and diversity of land resources for adaptation to environmental constraints are some important issues for identification and analysis in a rehabilitation programme $[23,25]$.

LSGS encompass some distinctive farming characteristics with regional variability and influence on environmental and social processes such as vegetation dynamics and abandonment. Farm size (from small to large holdings), property rights of grazing resources (from private to communal), management of herds/flocks (from continuous herding to free-ranging animals) and type of labour (from familiar to waged or from full to part-time job) are some distinctive features of particular LSGS [26].

LSGS are generally characterised by the use of indigenous livestock breeds, co-evolved with vegetation types. These breeds, together with the use of local grazing land resources are the two pillars of regional livestock products and markets.

\section{Operational Tools}

The concepts of pastoral survival strategies and management alternatives are largely operational and linked to the paradigm of sustainable intensification. If we assume that traditional grazing systems are not intrinsically unsustainable [27], one corollary is derived on the possibility of devising some management alternatives for the traditional LSGS to be continued. In other words, European LSGS cannot leave be fossilised. The subject of pastoral systems research is to prove that these alternatives exist, are operational and can be the subject of environmental, economic and social scrutiny [28].

Pastoral strategies and management alternatives can be differentiated by the range of application (systems-wide or systems-specific, respectively) and main actors for development and implementation (by pastoralists or pastoralists/experts, respectively), but they are not unrelated, as sensible management alternatives can be based on proper knowledge of how pastoral strategies are functioning.

Pastoral strategies are defined as those adaptive strategies implemented by pastoralists for the survival and continuation of the grazing operation. Pastoralists around the world survive the temporary and spatially variable distribution of grazing land resources, the threats posed by climatic constraints and the often inadequate and unstable institutional framework by engaging in strategies that increase their options. These strategies include options for mobility of herds/flocks, for access to alternative grazing grounds, for complementary forage resources or for mutual or cooperative forms of production. These strategies characterize many of the key practices and institutions that make pastoralism sustainable [25]. Pastoral strategies, in diverse forms according to particular systems, have been adopted for centuries but, in spite of that, many new developments require an adaptation to modern times. Recent decades have witnessed reduced mobility due to the agricultural expansion, unmanaged drove paths, increasing herding costs or scarcity of skilled labour. In Spain for example, the long distance transhumance system is mainly an historical event and more sedentary forms of production have been generally adopted [29]. Notwithstanding pastoral strategies, many traditional livestock systems in Europe are in a de-coupling state [11].

Conservation programmes are financed to deal with environmental values but the social subsystem of particular LSGS can be uncongenial and unstable due to globalisation and improvement of the regional economic outlook. Even if these extensive systems cannot be economically compared with their intensive counterparts, efforts should be made to improve their socio-economic sustainability $[30,31]$.

Management alternatives represent a step forward in the transition process of pastoral systems towards continuity and sustainable development. These alternatives represent changes in land use, production practices or even institutional and market reforms over current ways of conducting 
Table 1. Sampling schemes for grazing dependency of European rarities.

\begin{tabular}{|c|c|c|}
\hline${ }^{\text {a }}$ LSGS & ${ }^{\mathrm{b}}$ Grazing and post-grazing & ${ }^{\mathrm{c}}$ European rarities or target vegetation types \\
\hline \multirow{3}{*}{$\begin{array}{c}\text { Dehesa } \\
\text { (south-west of Spain) } \\
\text { Mixed cattle, sheep and Iberian pig }\end{array}$} & Grazing (high intensity) & \multirow{3}{*}{$\begin{array}{c}\text { Poa bulbosa-Trifolium subterraneum vegetation } \\
\text { type. Target bird (Grus grus) }\end{array}$} \\
\hline & Post-grazing (mid-term succession) & \\
\hline & Post-grazing (near climatic climax) & \\
\hline \multirow{3}{*}{$\begin{array}{l}\text { Sápmi (Fennoscandia) } \\
\text { Reindeer herding }\end{array}$} & Grazing (medium intensity) & \multirow{3}{*}{$\begin{array}{c}\text { Target animals (lemmings, long-tailed jaegers). } \\
\text { Red-listed plants. Snap-trapped microtine ro- } \\
\text { dents }\end{array}$} \\
\hline & Post-grazing (mid-term succession) & \\
\hline & Post-grazing (near climatic climax) & \\
\hline \multirow{2}{*}{$\begin{array}{c}\text { Cereal-sheep system } \\
\text { (south-central Spain) } \\
\text { Mixed arable and sheep farming }\end{array}$} & Post-grazing (mid-term succession) & \multirow{2}{*}{$\begin{array}{l}\text { Target steppe birds of open habitats (Great Bus- } \\
\text { tard) or grassland-dependent birds (Calandra) }\end{array}$} \\
\hline & Post-grazing (near climatic climax) & \\
\hline
\end{tabular}

${ }^{\text {a }}$ Large Scale Grazing Systems

${ }^{\mathrm{b}}$ Replicated independent samples within systems are required

${ }^{\mathrm{c}}$ Enough species specific data for finding patterns

pastoral business operations. In this sense, management alternatives are more system-specific than pastoral strategies and require a community-based research effort and concerted action of scientists and livestock farmers. The process is developed in three phases in the LACOPE project [14].

First, a base-knowledge of components and functions of particular systems is required including traditional management strategies. For example, in reindeer herding systems long- and short-migration strategies or even more stationary systems are operative and combined with strategies for compatibility of forest and reindeer management $[32,33]$. In the dehesa system of SW Spain, mixed grazing is combined with temporal- or no-tilling strategies [34], and in the cereal-sheep system of Castile-La Mancha (Central Spain), the integration of sheep is largely dependent on crop rotation strategies and tilling intensity: traditional cereal-fallow versus longer green fallow and integration of annual forage legumes [28].

Once knowledge-based management alternatives are devised, the second phase consists of testing these alternatives against appropriate economic, environmental and social functions. In our operational approach, we must include the management alternatives as an instrument to facilitating team work and interdisciplinary research. Changes in land use, grazing practices or even institutional management may have environmental and socioeconomic implications. Concerted research, components analysis of LSGS and conclusions are facilitated by individuals of several disciplines using the management alternatives as common treatments within particular pastoral systems (e.g., grazing intensity, mobile or more stationary grazing management).

More generalised conclusions will be achieved by sampling particular LSGS in different bio-geographical regions (inter-system research) and surveying enough species specific data for finding patterns $[35,36]$. Particular LSGS has to select a target plant, animal rarity or target vegetation type for study as object for environmental evaluation (e.g. redlisted plants on the calcium-rich mountains in Scandinavia and target steppe-birds in Castile-La Mancha). Within one LSGS and physically comparable habitat (e.g. dehesa), vastly different patterns of grazing use can be represented (Table 1).

At the end of the validation test, management alternatives may appear compatible or incompatible regarding economic and environmental criteria, and potential trade-offs can be valued. Social-ecological synergies for some alternatives are not disregarded (win-win situation). In this third phase, the most promising alternatives should be tested for implementation in the institutional and social context of particular systems. Some promising alternatives may find structural or social constraints for implementation or an unfavourable institutional setting (Fig. 1). In this phase, participatory research and consultation with livestock farmers is required. In our conceptual approach, we have stated the premise that traditional pastoral systems are not inherently uneconomic $[14,27]$ and we may find management alternatives that increase the profitability of traditional systems. This may have consequences for the institutional setting as well [23]. Under proper transition models, the regulatory framework would be the consequence and final stage of a research and development agenda [14]. In practice, ex-ante regulations are further assessed with doubtful or mixed results [37-39]. Transitional models of change are largely influenced by social context, and farmers' behaviour and institutional setting are related issues. 


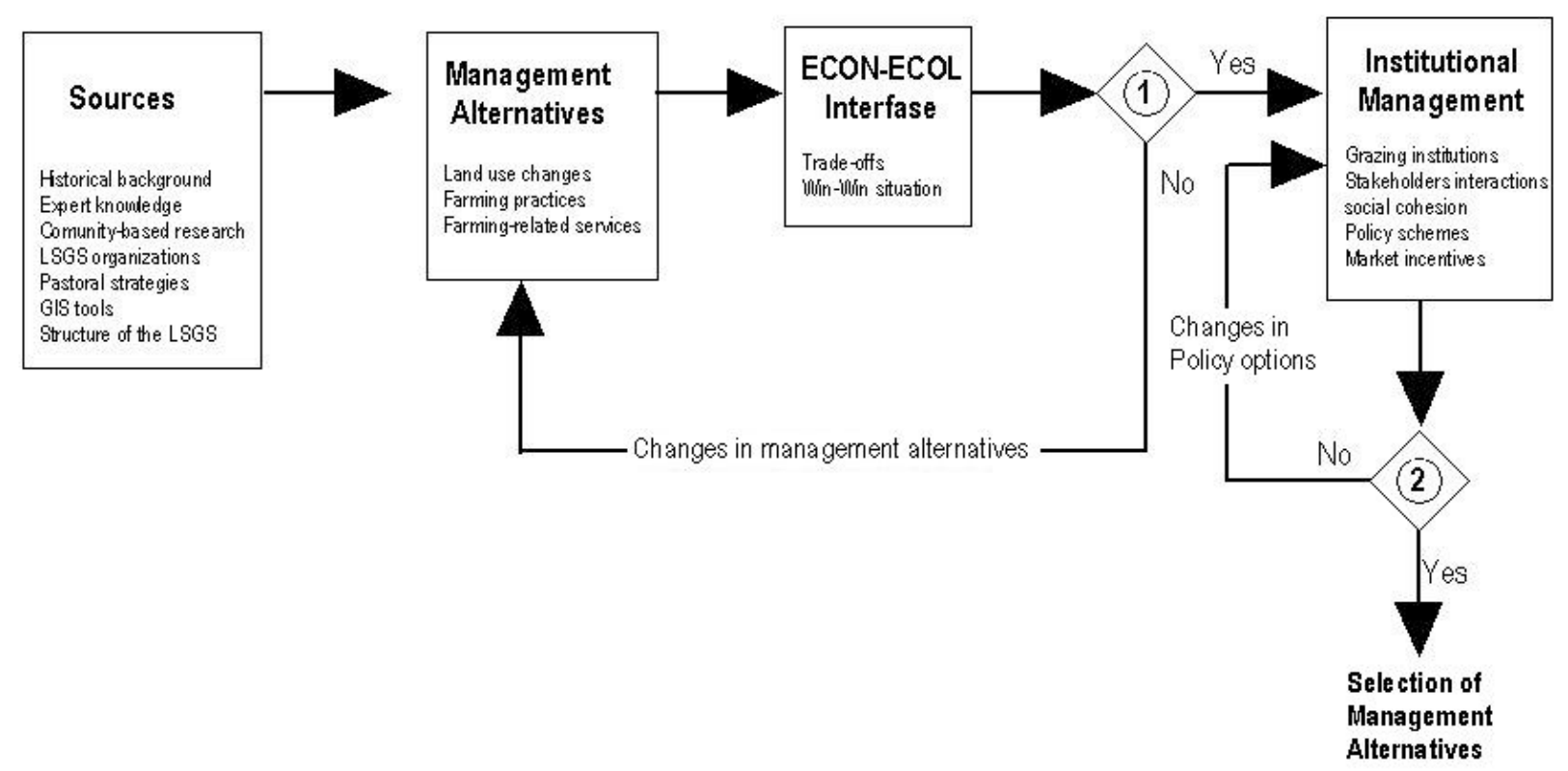

${ }^{1}$ ECON-ECOL test. Limited trade-offs between the two functions or win-win situation. If not, return to devise new alternatives.

${ }^{2}$ Institutional framework test. Policy schemes and the general institutional framework in favour of selected alternatives. If not, return for reforms in the institutional framework and conducive policies in favour of selected alternatives

Fig. (1). Policy options in Large Scale Grazing Systems (LSGS).

Table 2. Socio-economic status and grazing regulations in four Large Scale Grazing Systems (LSGS).

\begin{tabular}{|c|c|c|}
\hline \multirow{2}{*}{ Trend of Conservation } & \multicolumn{2}{|c|}{ Main Driver of Change } \\
\cline { 2 - 3 } & Largely Regulated & Largely Unregulated \\
\hline \hline Dynamic & ${ }^{\mathrm{a}}$ Reindeer & ${ }^{\mathrm{b}}$ Dehesa \\
\hline Downward & ${ }^{\mathrm{c}}$ Cereal-sheep & ${ }^{\mathrm{d}}$ Tatra mountains \\
\hline
\end{tabular}

${ }^{\mathrm{a}}$ Reindeer herding in Sami land (N Fennoscandia)

${ }^{\mathrm{b}}$ Mixed cattle, sheep and Iberian pig in South-west Spain

${ }^{c}$ Mixed cereal and sheep in South-central Spain

${ }^{\mathrm{d}}$ Lowland/upland pastures for dairy sheep in South-east Poland

Adapted from [27]

\section{EMPIRICAL MATERIAL}

\section{Trends in the Six Lacope Study Areas}

The starting point is the conventional or traditional system dominant in each study area. The possible alternatives result from management decisions that cause systems under study to change in a range that goes from more extensive to more intensive grazing systems. This process of change is triggered due to the action of a set of ecological and socioeconomic factors, which are at the same time causes of change but also bottlenecks to overcome. Although we may assume the logic of dynamic change, we should be aware that the process of change is embedded in the logic of farm managers with differential rates of change.

We may find dynamic or downward trends in LSGS that are either largely supported and regulated or largely unregulated, but probably very few dynamic systems when public support and regulations work against market incentives as in the cereal-sheep system of Castile-La Mancha. In this system, regional and EU grazing regulations and schemes of support work against incentives for the congenial use of land based resources of arable farmers and landless pastoralists [23]. In the Tatra Mountains, the semisubsistence system is largely unsupported and barely regulated but the summer camp system of sheep grazing in the upland clearings is also in a downward trend (Table 2). In both cases, an inappropriate or barely existing legal framework is hampering the region-specific use of grazing resources with consequent abandonment of outfields and land use changes.

An example of selected alternatives for the study areas of the LACOPE project is presented in Table 3 [27]. Here follows a brief account on how the management alternatives were selected following experts' account. 
Table 3. Management alternatives in the LACOPE study areas.

\begin{tabular}{|c|c|c|c|c|}
\hline $\begin{array}{l}\text { Northern Sapmi } \\
\text { (Fennoscandia) }\end{array}$ & Reindeer herding & $\begin{array}{l}\text { Alpine pastures (summer) and } \\
\text { tundra lichens (winter) }\end{array}$ & $\begin{array}{l}\text { Full migration, short migration } \\
\text { and stationary patterns }\end{array}$ & $\begin{array}{l}\text { Enlargement of herds. Supplemen- } \\
\text { tary winter feeding (hay). Unre- } \\
\text { stricted national borders }\end{array}$ \\
\hline $\begin{array}{l}\text { Allmende system } \\
\text { (Bavarian Alps) }\end{array}$ & $\begin{array}{l}\text { Heifers and dairy } \\
\quad \text { cattle }\end{array}$ & $\begin{array}{l}\text { Semi-natural pastures in the } \\
\text { Allmende and intensive grass- } \\
\text { lands in the lowland farms }\end{array}$ & $\begin{array}{l}\text { Heifers under part-time care in } \\
\text { Allmende (summer) and sta- } \\
\text { tionary dairy cattle in the farms }\end{array}$ & $\begin{array}{l}\text { Specialised heifers breeding and } \\
\text { suckling cow farms. Incentives for } \\
\text { use of alpine pastures (Allmende) } \\
\text { and skilled herding labour. Exten- } \\
\text { sification of lowland grasslands. }\end{array}$ \\
\hline $\begin{array}{c}\text { Tatra Mountains } \\
\text { (Polish Carpathians) }\end{array}$ & Dairy sheep & $\begin{array}{l}\text { Semi-natural pastures in the } \\
\text { clearing alps and lowland } \\
\text { meadows }\end{array}$ & $\begin{array}{l}\text { Winter feeding of meadows' } \\
\text { hay and summer grazing under } \\
\text { care of camp master (baca) in } \\
\text { the alps }\end{array}$ & $\begin{array}{l}\text { Clear-cut of land property and } \\
\text { grazing rights. Incentives for shep- } \\
\text { herding. Improvements of mobility } \\
\text { and cheese-making facilities }\end{array}$ \\
\hline $\begin{array}{l}\text { Montado/Dehesa } \\
\text { (Baixo Alentejo, } \\
\text { Portugal/SW Spain) }\end{array}$ & $\begin{array}{l}\text { Meat cattle and sheep } \\
\text { and Iberian pig }\end{array}$ & $\begin{array}{l}\text { Open forest of Quercus spp } \\
\text { (holm and cork oaks) and rain- } \\
\text { fed cereal-fallows }\end{array}$ & $\begin{array}{l}\text { Privately-owned fenced farms } \\
\text { with open or semi-enclosed } \\
\text { operation systems }\end{array}$ & $\begin{array}{l}\text { Specialised v mixed productive } \\
\text { orientation. Cultivated v un- } \\
\text { ploughed farms. Tree-regeneration } \\
\text { plans. Extensification of low- } \\
\text { productive farm units }\end{array}$ \\
\hline
\end{tabular}

Adapted from Work-package five of the LACOPE project [73]

In the Northern Sapmi study area of the LACOPE project, encompassing land in Norway, Sweden and Finland, reindeer management culture by Sámi herders is well entrenched in the area. Boreal forest/open tundra and natural alpine grassland dominate and can be used as winter and summer grazing grounds, respectively under traditional and nomadic management (long- and short-migration or stationary herding patterns). Currently, the use of different grazing grounds is hampered by restrictions in national borders and other, more intensive forms of production are envisaged such as enlargement of herds, intensification of reindeer productivity or winter feeding supplementation. Social empowerment of reindeer herders and co-adaptive management is looked for as well as proper pasture cycle with seasonal-use of different resources. Environmental, economic and social factors are involved with variants between countries \{ see [40] in Norway, [41] in Norway and Sweden, [33] in Sweden and $[42,43]$ in Finland $\}$.

In alpine-dominant areas such as Upper Bavaria, Swiss Alps (Entlebuch) and Polish Carpathians (Tatra Mountains), the most frequent concern is the uncoordinated use of lowland and upland pastures with different intensity levels. Management alternatives may envisage more extensive forms of production in the lowland grasslands of Bavaria and Entlebuch coupled with incentives for skilled herding labour and for sustainable use of upland pastures associated with social functions such as biodiversity and tourism [44]. In the Tatra Mountains, lowland and upland units are in need of better management and grazing infrastructures and a 
clear-cut land ownership and grazing rights allocation. Any one sheep farmer, who gathers the flocks of other small sheep farmers and takes them together to the summer camp in the alpine clearings, cannot claim for shepherding subsidies because of lack of proper renting contracts. In this case, legal and institutional bottlenecks may hinder the implementation of promising management alternatives.

In Mediterranean areas such as the southern Castilian Plain, the cereal-sheep system is dominant, but landowners (mainly arable farmers) and sheep farmers (mainly landless pastoralists) share the use of land units. Some management alternatives of land use changes (e.g. green fallows or annual legume crops) may deliver environmental and economic assets, even if the latter are not equally distributed between the two stakeholders, but can be hampered by a poor institutional framework or incompatible interests of the two social groups [20]. In the Montado system of Baixo Alentejo (Portugal), a land-leasing logic is dominant among landowners, favouring processes of land consolidation, enlargement of herds and specialized productive orientation coupled with abandonment of less productive farm units to alternative uses (e.g. hunting grounds or reforestation).

\section{Trends in forty-six European LSGS}

Transition to sustainable pastoral systems in Europe requires an assessment of the current variability in structure and functions and perception-views of experts on current disturbances and potential improvements. A summary of the main issues in a sample of 46 European LSGS is provided in this section. This descriptive summary arose from consultation with a sample of 46 corresponding experts carried out between October 2010 and May 2011 with a survey tool questionnaire [45]. Collaborative experts were identified by affiliation and main job discipline. For the former, $50 \%$ of them were university professors, $30 \%$ affiliated to mainly public research institutions and $20 \%$ experts/managers or advisory staff. For the latter, 63\% indicated expertise in environmental issues and $27 \%$ in socio-economic, animal production or grassland management. The largest European environmental zones were represented with $17 \%, 24 \%, 14 \%$, $15 \%$ and $30 \%$ of sampled LSGS located in the Atlantic, Alpine, Boreal, Continental and Mediterranean bioregions, respectively. The structure of the sample and extensive statistical analysis is recorded in [45].

Twenty-nine respondents provided data on the rate of exiting from farming in the last 60 years. For three wide geographical areas: Northern and Central Europe (eight observations), Eastern Europe (nine) and Mediterranean (12), the numbers were $1.04 \pm 0.33,0.55 \pm 1.17$ and $1.06 \pm 0.59(\%$ per year of livestock farmers), respectively.

Private and public ownership of grazing rights are present either as single or mixed mode. The mixed type prevails in a large minority of case studies (44\%). Frequently, the owners of grazing land resources are not the owners of livestock. Mixed modes of land ownership and grazing rights give way to mixed modes of governing allocation of grazing rights. Normative (formal) and informal rules are dominants and private contracts linked to private ownership. Market incentives for allocating grazing rights (i.e., rules allowing interchange of grazing rights) are less prevalent as well as case studies where ownership is under the aegis of some nature conservation body that may lease grazing rights to pastoralist under specific management contracts. The presence of grazing institutions governing grazing rights under formal rules does not assure proper management. Frequently, grazing rules are improperly designed or institutions lack the technical and managerial support for implementation (Table 4).

In the view of experts, the perception of a loss of identity for a majority of LSGS case studies (71\%) is not at risk, notwithstanding the ample evidence of environmental, economic and social disturbances cited by experts. Under the identity criteria, responses to particular indicators are encouraging. A large majority of experts (91\%) still recognized the regional identity of LSGS and they largely agree or strongly agree on considering LSGS still as a grazingdominant and herding operation with grazing land resources as the main source of livestock feeding (80\%). In the minority of case studies of experts rating undecided or disagreement, they cited their LSGS towards a more intensive and indoor-feeding operation or extensive LSGS as a relic of the past and currently surviving as a spot of biodiversity at a lower spatial scale. Also they still recognized a community of livestock farmers making a living from a workable and cultural landscape (72\%). Much less encouraging is the view of experts on the perception of the society as a whole towards the cultural values of LSGS. In this case, only a minority $(39 \%)$ agrees or strongly agrees on a positive perception.

The survey questionnaire elicited a response on the main environmental functions and side line economic activities supported by the LSGS operation. A summary of responses is recorded in Table 5. The experts' response clearly showed the link between LSGS and biodiversity assets regulated in EU directives for the presence of vegetation types (98\%), endemic or rare plant species $(91 \%)$ and animal species of conservation concern (96\%). As our sample of 46 European LSGS cut across the main environmental zones and dominant land uses, it is probable that a large part of regulated biodiversity assets is represented, although we have not performed much needed exercise. In a sample of 15 Spanish LSGS located in three environmental zones (Alpine, Atlantic and Mediterranean) we reported the presence of 76 out of 216 vegetation types in the EU Habitat Directive [2].

On the other hand, issues of concern are also abundant and recorded in the perception of experts to 24 criteriavariables of identity (A), environmental (B), economic (C) and social (C) character (six variables by each criterion). The aggregates by each criterion and the total score were calculated in the 46 LSGS. In Table 6 we present the wording and scoring of the 12 low-scoring variables (most important issues of concern) in the subsamples of the top-eight and loweight scoring LSGS as rated by the total score. This latter variable showed normal distribution while the distribution of particular variables in the whole sample was asymmetrical. The comparison of extreme case studies is thus more illuminating. 
Table 4. Modes of governance, risks and beneficial management alternatives in 46 European Large Scale Grazing Systems (LSGS).

\begin{tabular}{|c|c|c|c|c|}
\hline Factor & Level & Frequency & $\%$ & Notes \\
\hline \multirow{2}{*}{${ }^{\mathrm{a} O w n e r s h i p ~ o f ~ g r a z i n g ~ r e s o u r c e s ~}$} & Private & 14 & 30 & \multirow{2}{*}{$\begin{array}{l}{ }^{\text {a }} \text { Public, under some scale of government } \\
\text { control (national, regional or local) }\end{array}$} \\
\hline & Mixed & 20 & 44 & \\
\hline \multirow{3}{*}{$\begin{array}{l}{ }^{\mathrm{b}} \text { Mode of governing grazing } \\
\text { rights }\end{array}$} & Informal rules & 19 & 41 & \multirow{3}{*}{$\begin{array}{l}{ }^{\mathrm{b}} \text { Does not add to } 100 \% \text { because experts indi- } \\
\text { cated more than one mode }\end{array}$} \\
\hline & Private contracts & 11 & 24 & \\
\hline & Marketing incentives & 9 & 19 & \\
\hline \multirow{4}{*}{$\begin{array}{l}{ }^{c} \text { Perception-views of experts } \\
\text { (risks by criteria) }\end{array}$} & General identity & 79 & 29 & \multirow{4}{*}{$\begin{array}{l}{ }^{\mathrm{c}} \text { Global response by criteria ( } 276 \text { observations } \\
\text { by criteria, } 46 \text { study areas by six indicators) }\end{array}$} \\
\hline & Environmental & 133 & 48 & \\
\hline & Economic & 125 & 45 & \\
\hline & Social & 128 & 46 & \\
\hline \multirow{2}{*}{ Type of constraints } & ${ }^{\mathrm{d}}$ Internal & 62 & 45 & \multirow{2}{*}{$\begin{array}{c}{ }^{\mathrm{d}} \text { Three top constraints cited by experts on } 46 \\
\text { areas }{ }^{\mathrm{e}} \text { Response to indicator } \mathrm{D}_{5} \text {. Undecided } \\
\text { rated as both }\end{array}$} \\
\hline & External & 76 & 55 & \\
\hline \multirow{7}{*}{$\begin{array}{l}{ }^{\mathrm{f}} \text { Type of beneficial management } \\
\text { alternatives cited by experts for } \\
\text { their corresponding grazing } \\
\text { systems }\end{array}$} & Market capabilities & 24 & 55 & \multirow{7}{*}{ 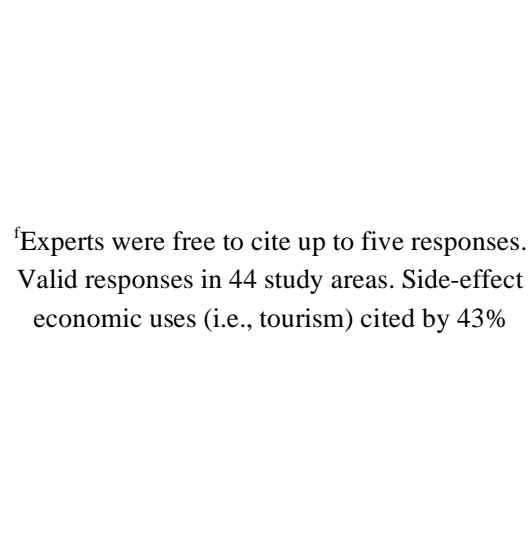 } \\
\hline & Herding labour & 18 & 41 & \\
\hline & Graze infrastructures & 15 & 34 & \\
\hline & Social empowerment & 14 & 32 & \\
\hline & Grazing governance & 13 & 30 & \\
\hline & Technical support & 11 & 25 & \\
\hline & Land use changes & 4 & 9 & \\
\hline
\end{tabular}

For those LSGS sharing a low total score and the most evident downward trend, progress toward sustainability can be reached by amending the 12 low-scoring variables and particularly those variables showing significant mean differences with the subsample of the top-scoring LSGS (variables $A_{3}, A_{4}, B_{3}, D_{2}$ and $D_{3}$ ). But this latter subsample is not devoid of failings and general concerns were attached to variables $\mathrm{B}_{2}, \mathrm{~B}_{4}, \mathrm{~B}_{5}, \mathrm{C}_{1}, \mathrm{C}_{4}, \mathrm{C}_{6}$ and $\mathrm{D}_{4}$ with particular and general consensus and concern attached to $B_{2}, C_{1}$ and $C_{4}$ (Table 6). Thus in the whole sample a large majority of respondents
(76\%) showed concern on the heterogeneous pattern of grazing distribution across the potential grazing area (variable $\mathrm{B}_{2}$ ); all experts disagree or strongly disagree that the LSGS operation can be profitable without some type of agricultural policy support (variable $\mathrm{C}_{1}$ ); and also a large majority $(76 \%$ with an additional $15 \%$ undecided) that the community of livestock farmers has proper financial and technical capabilities and social organization for access to markets (variable $\mathrm{C}_{4}$ ). Responses of experts to concerning constraints corresponded with amending proposals. 
Table 5. Main environmental functions and side effect activities linked to 46 European Large Scale Grazing Systems (LSGS) as cited by corresponding experts.

\begin{tabular}{|c|c|}
\hline 1. Environmental functions & \% of Experts Citing \\
\hline Vegetation types listed in the EU directive represented & 98 \\
\hline Animal species of conservation concern represented & 96 \\
\hline Contribution to maintenance of indigenous livestock breeds & 76 \\
\hline Contribution to water management and watershed stewardship & 50 \\
\hline Contribution to control of fires' risk & 39 \\
\hline Contribution to control of soil erosion processes & 37 \\
\hline Agro-tourism and eco-tourism & 89 \\
\hline Landscape scenery & 89 \\
\hline Cultural heritage and traditions & 76 \\
\hline Hunting & 50 \\
\hline Others (e.g. outdoor sports, second residence) & 25 \\
\hline
\end{tabular}

They were free to cite up to five beneficial management alternatives in the face of current management practices. We grouped the responses on nine types of actions and calculated the frequency of observations by type (Table 4). The top-cited responses were related to some change or improvement in agro-pastoral or silvo-pastoral management or proper design and implementation of grazing plans (82\%), policy reforms $(59 \%)$, quality assurance and marketing capabilities of local products $(55 \%)$, enhancement of side line economic activities such as tourism (43\%), support to herding labour $(41 \%)$, improvement of grazing infrastructures $(34 \%)$ or social empowerment of farming communities $(32 \%)$.

This summary of results showed two main points. First, that European LSGS, notwithstanding a large variation in physical environments, still share many assets and constraints, the latter addressed by a common set of key actions and proposals (beneficial management alternatives). The question that then arises is whether we will be able to plan and design sustainable LSGS at the inter-regional scale. That question can and must be answered positively. However, a majority of experts $(61 \%)$ did not agree with the attachment of farmers to the delivery of public goods as a rationale for public support. Thus, the wider consensus on the set of beneficial management alternatives seems to be a better approach in designing and implementing a framework of policy in support of LSGS than the rationales of public money for public goods [46] or strengthening farmers' link to nature values [11].
Secondly, that a majority of European LSGS, not withstanding the many types of disturbances cited by experts, still showed a cultural resilience regarding their identity values and on the feasibility of reverting towards sustainable development. Traditional uses are prevalent on remote areas of most developed countries (e.g. Scandinavian countries, Scotland and Wales (UK), Ireland) or in less developed regions of recently accessed countries from Eastern Europe (Romania, Bulgaria). In the EU Mediterranean countries, we can find a wide array of situations with the two main drivers of change (remoteness and regional development) being operational. In the last 60 years, the rate of abandonment in Spain, Italy and Greece has accelerated, and for no longer traditional LSGS of these countries can be considered as repository of European natural values under the current trend [2]. In most developed regions of Central and Western Europe, the presence of traditional LSGS is becoming purely testimonial and currently surviving as small scale spots mainly oriented to nature conservation.

\section{DISCUSSION}

The trend towards abandonment of traditional forms of production in the LFA of Europe is widespread [47, 48]. General trends in landscape changes are quite well know but planning and managing changes remains difficult and extremely uncertain [49]. The European Landscape Convention [50] defines landscapes in a broad sense, including natural and cultural landscapes, and stresses the importance of 
Table 6. Wording and scoring of the 12 low-scoring criteria-variables in the eight top and the eight low-scoring LSGS case studies

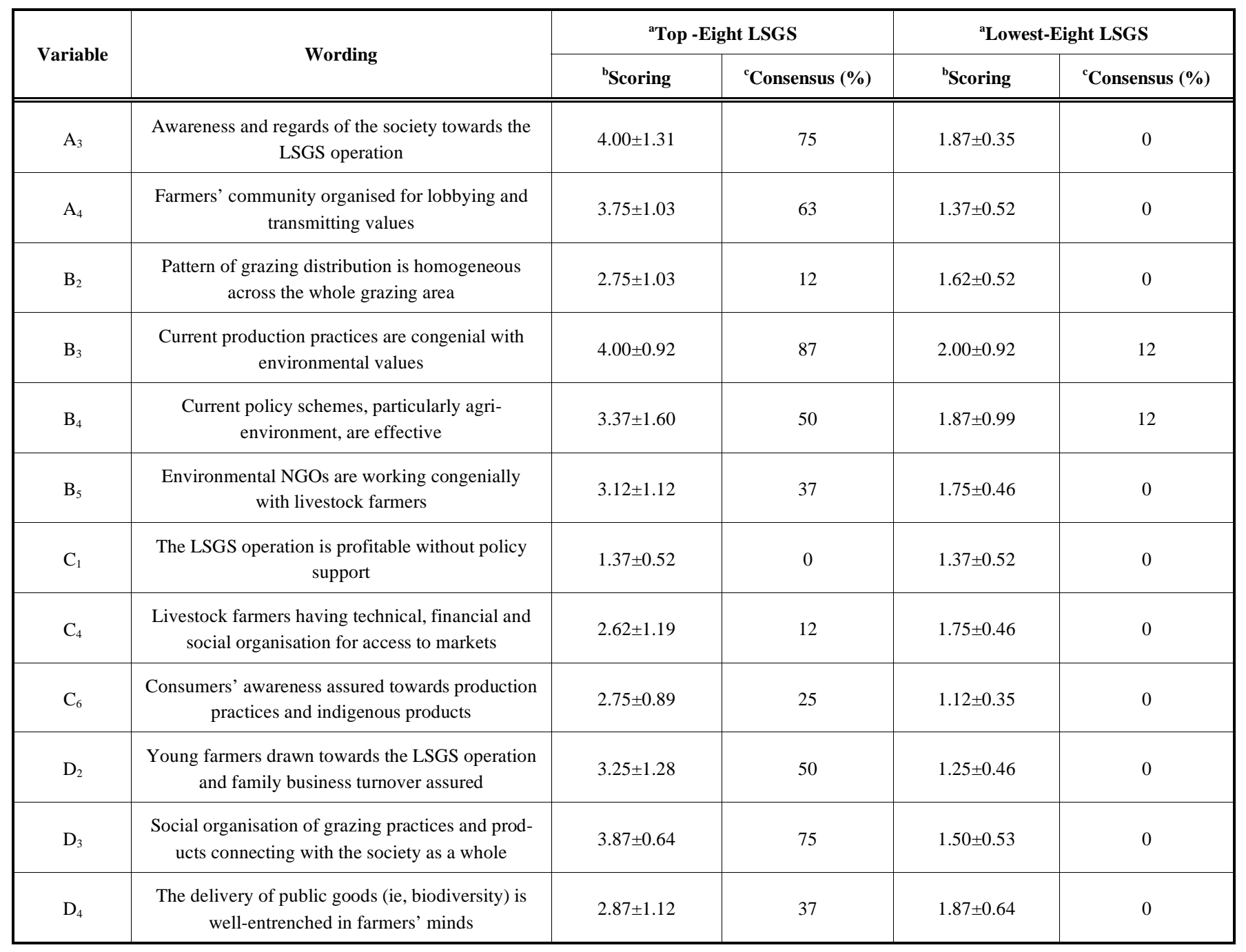

${ }^{\mathrm{a}}$ Top- or low-scoring LSGS case studies in the total score of 24 criteria-variables.

${ }^{b}$ Mean score of the eight case studies in the Likert-type scale. Maximum is 5 (strongly agree); minimum is 1 (strongly disagree).

${ }^{c}$ Percentage of experts rating agree or strongly agree.

regional identity as a cultural heritage, but offers little insight on sensible pathways of change and management. In this research we have focussed the attention on an important part of European cultural landscapes: the Large Scale Grazing Systems (LSGS) or extensive European systems of grassland management of recognized natural value but uncertain future [51].

Transition is viewed as a reversal point in time in the trend of some variables or functions. Changes from traditional forms of production to more sedentary, mixed and intensive forms are common in Europe. Although the process is common, the reversal point is not uniform in space and time. In the most developed regions of Europe, the turning point has been reached a long time ago, and their traditional livestock practices are a relic of the past [52] or in a progressive intensification process [53]. Some authors select World War II as an important turning point for depopulation of less favoured rural areas [54]. In particular countries, such as the UK singular events are of significance such as the culling after the 2001 Foot and Mouth disease outbreak together with the general change from headage to area-based support payments. In other less developed and recently accessed countries such as Romania and Bulgaria, traditional forms of livestock production still persist, but under stress of abandonment or conventional intensification [55]. For the latter, post-communist changes are relevant [56].

The dominant research on the land intensification/extensification processes frequently addressed the environmental consequences of farmland abandonment [57-59] but much less the socio-economic drivers of farm abandonment at the spatial scale of pastoral farming systems and particularly LSGS. We must find ways of maintaining the dynamics of cultural and natural processes. We have developed the concept of sustainable intensification as an adative form of management strategies in response to stressing conditions such as grazing land seasonal production or scarcity of herding labour, not as a deliberate management decision to increase input levels in order to achieve higher production 


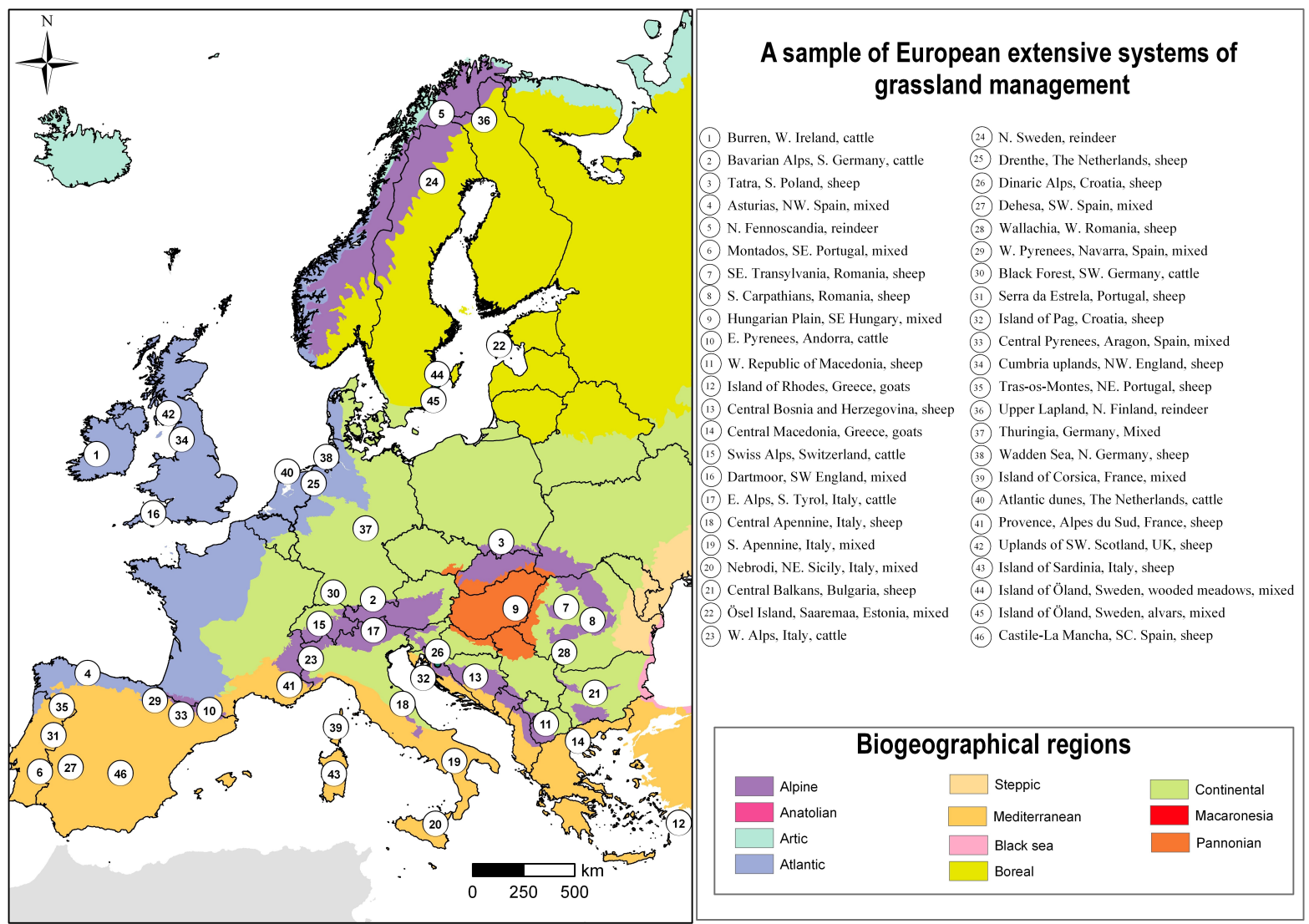

Map 1. A large sample of European Large Scale Grazing Systems. Base map [15, 17, 19].

and/or productivity. Improvements of mobility (better drove paths and transport facilities), accessibility (allocation of grazing rights or mutual use of grazing grounds), diversity of resources (year-long co-ordinated feeding programmes), market capabilities, social cohesion and institutional reforms are aimed at the continuation of the herding operation, but may require the use of higher input levels. Increasing the use of capital, technology and skilled herding labour under adaptive strategies does not mean, in our conceptual approach, that the system is intensifying. Partial substitution of major inputs such as feed is likely to change the financial and labour outlays of production. In this sense, we will consider in this research that, when the increase of input(s) is not directly oriented to achieve greater output(s), but represents an adaptive response to some stressing conditions, we cannot properly talk of intensification.

Interdisciplinary job is a predicate of the sustainable intensification concept. Management alternatives should be tested for social-ecological effects before being included as key actions for development and the framework profile is a pool of social-ecological attributes. Against the conceptually inaccessible hypothesis, our results in the six LACOPE study areas showed how fruitful interdisciplinary job was carried out (Tables $\mathbf{1 , 2}$ and $\mathbf{3}$ ). In the 46 additional study areas, our results showed that the experts' discipline \{Factor 3 in the variance analysis [46]\} barely influenced their response to criteria-variables (only one criterion out of 24) and constraints (only one out of 10). Our results showed that interdisciplinary job is not only possible but also recommended as systems' functions are inter-related in the real world. Risk by criteria (environmental-economics-social) showed similar weights (Table 4) and, in the response of experts, environmental functions paired with economic side line activities (Table 5). However, variables under the economic and social criteria are more influential on the fragile state of LSGS (Table 6).

The sustainable intensification concept has been largely devised and tested in the less developed countries under stressing environmental conditions (ie, overgrazing), food scarcity of production systems and population pressure [60-62]. This is the North-South divide cited by Giller in [63]. Much less attention has been given to its potential application in affluent countries where the main threat is marginalisation of large expanses of land and livestock farmers exiting from farming. 
The agricultural policy dimension of this research can be addressed at the spatial scale and the effectiveness of particular schemes of support. The two dominant landscape scales, LFA and Natura 2000, do not capture the underlying features of farming systems. The LFA legal proposal is designated by the $\mathrm{EU}$ on the basis of natural handicaps on land productivity or remuneration for nature conservation. In Spain for example some $80 \%$ of the rural territory is designated as LFA. However, delineation of LFA in current legislation is made by Member States (MS) and eligibility for payment is a MS decision. Furthermore, they have the possibility of adding agri-environmental schemes specifically targeted to High Nature Value (HNV) farmland. It is hard to see how this broad scheme will be capable of reflecting the regional subtleties of Spanish rural life. Natura 2000 relies mainly on the habitat/biotope perspective. It is a useful scheme for identification of vegetation types and plant and animal species of European conservation concern, but barely an operational scale for regeneration of marginal rural land as it is unlinked to underlying farming systems. In this respect, Natura 2000 should be rather considered as a work in progress than a fully developed doctrine [64].

It is ironic that the EU has, for many years, "constructed" somewhat artificial spatial scales and corresponding support schemes while disregarding real operational and historical structures in danger of abandonment. It is therefore not a surprise that the EC is uncomfortable with current spatial schemes: "Natura 2000 and the conservation of threatened species will not be viable in the long-term" and "key actions are required to prevent intensification or abandonment of HNV farmland and supporting their restoration" [65]. Although this latter document refers to biodiversity and not to the CAP, we yet unknown how these key actions materialise without providing some empirical evidence on beneficial management alternatives for the LSGS (Table 4) dominant in the LFA where a large part of environmental assets are concentrated.

Aware of these weaknesses, the EU Commission intended to define and re-introduce the concept of HNV farmland as an operational landscape tool [66]. Until now, the focus has been on mapping HNV areas in Europe under some distinguishing criteria [19], but largely away from where it really belongs (the farm and the farmer). One attempt to redesign past schemes (LFA, Natura 2000) with the $\mathrm{HNV}$ concept is also reported [67]. The definition of $\mathrm{HNV}$ is somewhat blurred and not yet fixed, and the EU and individual Member States were commissioning studies on this issue $[68,69]$. These studies had the scope of clearing the open question of HNV definition. The exact delineation and targeting of the areas is competence of the authorities managing the Rural Development Plans (RDP). In short, the HNV concept should definitely jump from the land cover and farmland to the farming system realms. The first can be operative for the study and classification of natural assets (ie, biodiversity), but the second is the proper spatial scale where natural and cultural values can be coupled. Within this second realm, LSGS are a great part of European HNV farming systems [70].
Under World Trade Organisation (WTO) rules payments to farmers of the type provided by LFAs, Nature 2000 or agri-environment schemes must be calculated under rationale of the income foregone and extra costs approach. A second clause states that payments are made in relation to available budget of MS. But under current degraded state many LSGS traditional farms in marginal areas are operating at a financial loss and there is no income to forego. In this case, new and alternative rationales are proposed without breaking the WTO rules such as paying for the full, marginal or opportunity cost of the operation [71] or rationale of providing environmental benefits [72] which is on discussion on whether it is WTO compliant. None of these schemes is aimed at promoting endogenous development, but to pay for delivery of potential environmental assets. We may, however, design endogenous and supportive legal proposals (e.g. herding support payments; incentives to social cohesion of grazing institutions), something that has not always been the case [23].

The promotion of support to farming to deliver wider public goods has been driven by institutions interested in nature conservation and sustainable development [9] and picked up by the European Commission as a rationale for the next CAP reforms post 2013. Even if there is possibility of shifting Pillar 1 funds to LFA, this is a rationale to bring support to all farmers and is not likely to target marginal areas of higher potential assets. On this issue a large majority of experts (61\%) disagreed that livestock farmers used this rationale when planning and implementing their management practices. This rationale only holds for a small number of small-scale spots orientated to nature conservation where farmers are linked to conservation practices under contractual agreements (the Atlantic arch from France to Denmark). An alternative to this rationale would be to focus public funds on targeted beneficial management practices cited by experts and, by association, distinguishing systems by their potential delivery of public goods.

We have proven how management alternatives cited by farmers and key actions cited by experts are the base for improvement of LSGS under a dynamic approach. The sustainable intensification approach is measurable in the way that management alternatives and key actions of particular systems are unveiled and their social-ecological effects assessed under a community-based knowledge system. In time of budgetary constraints and demand of food quality products, the quest for green growth cannot be disregarded.

In conclusion, current European pastoral systems are recognized as repositories of natural values and cultural heritage but face an uncertain future. We have shown how these systems are not inherently unprofitable and that there are alternatives to improve their options. These alternatives are system-specific, but could be supported by a general policy framework and rationale of targeting funds and removing constraints.

Most European LSGSs are production oriented and a minority is small scale operations orientated to nature conservation. The current support system is based on a 
De-coupling of social-ecological functions and affinity to the latter that is not supported by our data. Measurements to promote endogenous development are underrepresented. We have provided evidence of beneficial management and key actions to be supported, but how these actions can be entrenched in the current support system is unclear.

We have proposed and tested transition pathways, management tools and policy frameworks to handle these changes for the preservation of cultural and environmental values. These pathways of change, however, cannot disregard market-oriented and endogenous initiatives as main drivers of change. As most European LSGS have not reached an irreversible situation, we still have time to reverse the general downward trend by planning and supporting for continuity and coherence of their territorial identity values. European societies may like to see this happen, but the time available for action is limited.

\section{CONFLICT OF INTERESTS}

The author confirms that this article content has no conflicts of interest.

\section{ACKNOWLEDGEMENTS}

The author wishes to thank the following representative experts for their contributions in filling out the 46 questionnaires on the territorial identity of European LSGS and further narrative comments and explanations to their responses: Brendan Duncan (case study $\mathrm{N}^{\circ} 1$ in the map), Norbert Röder (2), Ewa Tyran (3), Juan Antonio Valladares (4), Niklas Labba (5), Teresa D. Soares and Augusta Costa (6), Nathaniel Page and Razvan Popa (7), Sally Huband (8), Geza Nagy (9), Rosario Fanlo (10), Suzana Kratovalieva (11), Nikos Theodoridis (12), Senija Alibegovic and Muhamed Brka (13), Anna Sidiropoulou and Vasilios P. Papanastasis (14), Pius Hofstetter (15), Andy Guy and Ian Condliffe (16), Giovanni Peratoner (17), Paride D’Ottavio (18), Lucia Sepe and Salvatore Claps (19), Tommaso La Mantia and Salvatore Pasta (20), Iva I. Apostolova (21), Tiiu Koff (22), Giampiero Lombardi (23), Anna Berg and Ulf Segerström (24), Berien Elbersen (25), Antun Alegro and Renata Sostaric (26), Fernando J. Pulido (27), Veronica Sarateanu (28), Rosa M. Canals (29), Rainer Luick (30), Jan Jansen (31), Ivica Ljubicic (32), Federico Fillat (33), Terry McCormick, Stephen Lard and Lois Mansfield (34), Marina Meca Ferreira de Castro (35), Bruce Forbes and Ari Laakso (36), Edgar Reisinger (37), Martin Stock (38), Martin Vadella (39), Marijn Nijssen (40), Jacques Lasseur (41), Davy McCracken (42), Pier Paolo Roggero and Simonetta Bagella (43), Marie-José Gaillard $(44,45)$. Particular thanks are due to Norbert Röder, Davy McCracken, and Lucia Sepe for their amendments and comments to a first draft of this paper. The author wishes to thank partners of the EU-funded LACOPE project (Contract EVK2-CT-2002-00150) for discussion and implementation of the LSGS concept and descriptions of the six LACOPE case studies, and to Xavier Fernández Santos in drafting the map.

\section{REFERENCES}

[1] Emanuelsson U. The rural landscapes of europe-how man has shaped european nature. Forskningsrâdet Formas. Stockholm, Sweden 2009.

[2] Caballero R, Fernández-González F, Perez Badía R, et al. Grazing systems and biodiversity in Mediterranean areas: Spain, Italy and Greece. Pastos 2009; 39: 4-154.

[3] Caraveli H. A comparative analysis on intensification and extensification in mediterranean agriculture: dilemmas for LFAs policy. $\mathrm{J}$ Rural Stud 2000; 16: 231-42.

[4] Marriott CA, Fothergill M, Jeangros B, Scotton M, Louault F. Long-term impacts of extensification of grassland management on biodiversity and productivity in upland areas. A review. Agronomie 2004; 24: 447-62.

[5] Hopkins A, Holz B. Grassland for agriculture and nature conservation: Production, quality and multifunctionality. Grassland Sci Eur 2005; 10: 15-29.

[6] Bignal EM, McCracken DI. The nature conservation value of European traditional farming systems. J Appl Ecol 2000; 33: 41324.

[7] Stoate C, Baldi A, Beja P, et al. Ecological impact of early $21^{\text {st }}$ century agricultural change in Europe-a review. J Environ Manage 2009; 91: 22-46.

[8] Kleijn D, Rundlo M, Scheper J, Smith G, Tscharntke T. Does conservation on farmland contribute to halting the biodiversity decline? Trends Ecol Evol 2011; 26: 474-81

[9] IEEP. Public goods emerging as a central rationale for future CAP support. Institute for European Environmental Policy (IEEP). CAP Policy Briefing $\mathrm{N}^{\mathrm{o}}$ 7. London 2010.

[10] Ostrom E. A general framework for analysis in social-ecological systems. Science 2009; 325: 419-22.

[11] Fischer J, Hartel T, Kuemmerle T. Conservation policy in traditional farming landscapes. Conserv Lett 2012; 5: 167-75.

[12] Pratt DJ, Lusigi WJ. Best practices in rangeland management: experiences from world bank projects. In: west ne, ed. rangelands in a sustainable biosphere. Proceedings of the Fifth International Rangeland Congress Denver, CO 1995. pp. 328-329.

[13] Poux X. Is extensive agriculture still defendable? La Cañada 2008; 23: $5-7$

[14] Caballero R. High nature value (HNV) grazing systems in europe: a link between biodiversity and farm economics. Open Agr J 2007; 1: $11-9$.

[15] Landscape development, biodiversity and co-operative livestock systems in Europe. Document of Work (DoW). LACOPE Research Proyect N ${ }^{\circ}$ EVK2-CT-2002-00150, Stuttgart, Germany: LACOPE 2002

[16] Caballero R, Gil A, Fernandez-Santos X. An expert survey on sustainability across twenty-seven extensive European systems of grassland management. Environ Manage 2008; 42: 190-9.

[17] Metzger MJ, Bunce RGH, Jongman RHG, Mücher CA, Watkins JW. A climatic stratification of the environment of Europe. Global Ecol Biogeogr 2005; 14: 549-63.

[18] EC. Interpretation Manual of European Union Habitat-EUR 25. European Commission. D.G. Environment-Nature and Biodiversity. Brussels, Belgium 2003.

[19] IEEP. HNV Indicators for Evaluation. Final report for DG Agriculture. Institute for European Environmental Policy. Contract notice 2006-G4-04., Brussels, Belgium 2007

[20] Caballero R. Stakeholders interaction in Castile-La Mancha, Spain cereal-sheep system. Agr Hum Values 2009; 26: 219-31.

[21] Luik R, Jones G, Oppermann R. Semi-natural vegetation pastures, meadows and related vegetation commnities. In: Oppermann $\mathrm{R}$, Beaufoy G, Jones G, Eds. High nature value farming in europe. Verlag regionalkultur, Ubstadt-Weiher 2012, pp. 32-57.

[22] Opdam P, Verboom J, Pouwels R. Landscape cohesion: an index for the conservation potential of landscapes for biodiversity. Landscape Ecol 2003; 18: 113-26.

[23] Caballero R, Fernández-Santos X. Grazing institutions in CastillaLa Mancha, dynamic or downward trend in the cereal-sheep system. Agric Syst 2009; 101: 69-79. 
[24] Di Lacovo F. Social farming: dealing with communities, rebuilding the local economy. Rural Futures: dreams, dilemmas, dangers. University of Plymouth, UK 2008.

[25] Fernandez-Gimenez ME, Le Febre S. Mobility in pastoral systems: dynamic flux or downward trend? Int J Sust Dev World Ecol 2006; 13: 341-62.

[26] Caballero R. Typology of cereal-sheep farming systems in CastileLa Mancha (South-central Spain). Agric Syst 2001; 68: 215-32.

[27] Caballero R, Riseth JA, Labba N, et al. Comparative typology in six european low-intensity systems of grassland management. Adv Agron 2007; 96: 351-420.

[28] Caballero R, Gil A. Binding constraints in Castile-La Mancha, Spain cereal-sheep System. J Sustain Agr 2009; 33: 3-27.

[29] Ruiz Martín F, García Sanz A. Mesta, Trashumancia y Lana en la España Moderna. Critica-Grijalbo, Barcelona, Spain 1998.

[30] Dobbs TL. Multifunctional economic analysis. In: Ricker D, Francis C, Eds. Agroecosystem Analysis. American Society of Agronomy, Madison WI 2004, pp 75-92.

[31] Dobbs TL, Pretty JN. Agri-environmental stewardship schemes and "multifunctionality". Rev Agric Econ 2004; 26: 220-37.

[32] Kumm KI. Does re-creation of extensive pasture-forest mosaics provide economically sustainable way of nature conservation in Swedish's forest dominated regions? J Nat Conserv 2004; 12: 21318 .

[33] Berg A. Reindeer herding and modern forestry. The historical impact on forest of two main land users in Northern Sweden. Doctoral Thesis $N^{\circ}$ 2010:45. Swedish University of Agricultural Sciences. Umea, Sweden 2010.

[34] Plieninger T, Pulido FJ. Dehesa, Spain: blending grasslands, crops and forests. In: Veen P, Jefferson R, de Smidt J, van der Straaten J, Eds. Grasslands in Europe of high nature value. KNNV Publishing, Zeist, The Netherlands 2009, pp. 274-283.

[35] Oksanen, L, Trautner J, Kaule G, Scheidegger C. Condensed results of ECOL studies. Final Report, Section 6.4.1. LACOPE Contract EVK2-CT-2002-00150, Stuttgart, Germany 2006.

[36] Oksanen L, Trautner J, Kaule G, Scheidegger C. Sucessional trajectories. Final report Part I. Introduction. LACOPE Contract EVK2-CT-2002-00150., Stuttgart, Germany 2006.

[37] Kleijn D, Baquero RA, Clough Y, et al. Mixed biodiversity benefits of agri-environment schemes in five European countries. Ecol Lett 2006; 9: 243-54.

[38] Poux X, Beaufoy G, Bignal E, Hadjigeorgiou I, Ramain B, Susmel $P$. Study on environmental consequences of sheep and goat farming and of the sheep and goat premium system. Directorate General for Agriculture and Rural Development. Contract: 30-CE-0042768/0019. Brussels, Belgium 2006.

[39] Whittingham MJ. Will agri-environment schemes deliver substantial biodiversity gain, and if not why not? J Appl Ecol 2007; 44: 15 .

[40] Riseth JA, Johansen B, Vatn A. Aspects of a two pasture-herbivore model. Rangifer (special issue) 2004; 15: 65-82.

[41] Rönnegard L. Selection, maternal effects and inbreeding in reindeer husbandry. PhD dissertation. Swedish University of Agricultural Sciences. Uppsala, Sweden 2003.

[42] Kumpula J. Productivity of the semi-domesticated reindeer (Rangifer tarandus) stock and carrying capacity of pastures in Finland during 1960-1990s. PhD dissertation. Oulu University Press, Oulu, Finland 2001.

[43] Forbes BC. The challenges of modernity for reindeer management in Northernmost Europe. In: Forbes BC, et al. Eds. Reindeer management in northernmost Europe: linking practical and scientific knowledge in social-ecological systems. Springer, Berlin: Ecological Studies 2006; 184: 11-25.

[44] Hofstetter P, Röder N, Bergamini A, et al. Impact of Swiss agroenvironmental policy on cattle farming and target species in the Entlebuch UNESCO Biosphere Reserve. Grassland Sci Europe 2007; 12: 496-9.

[45] Caballero R. The Territorial Identity of Large Scale Grazing Systems in Europe. Sci Rep 2012; 1: 474.

[46] Cooper T, Hart K, Baldock D. Provision of public goods through agriculture in the European Union. Report prepared for DG Agriculture and Rural Development. Contract 30-CE-0233091/00-28. Institute for European Environmental Policy. London 2009.
[47] Breustedt G, Glauben T. Driving forces behind exiting from farming in Western Europe. J Agr Econ 2007; 58: 115-27.

[48] Keenleyside C, Tucker GM. Farmland abandonment in the EU: an assessment of trends and prospects. Report prepared for WWF. Institute for European Environment Policy (IEEP). London 2010.

[49] Antrop M. Why landscapes of the past are important for the future. Landscape Urban Plan 2005; 70: 21-34.

[50] Council of Europe. The European Landscape Convention. European Council. Strasbourg 2000.

[51] Veen P, Jefferson R, de Smidt J, van der Straaten J. Grasslands in Europe of high nature value. KNNV Publishing, Zeist, The Netherlands 2009; pp. 319.

[52] Luick R. Transhumance in the Swabian-Franconian region of Germany. La Cañada 2008; 22: 4-7

[53] Riseth JA. Sámi reindeer herd managers: Why do they stay in a low-profit business? Brit Food J 2006; 108: 541-59.

[54] Cavallero A, Bassignana M, Iuliano G, Reyneri A. Sistemi foraggeri semi-intensivi e pastorali per l'Italia Settentrionale: analisi di risultanze sperimentali e dello stato attuale dell'alpicoltura. Rivista di Agronomia 1997; 31: 482-504.

[55] Draganescu C. Romanian strategy for the management of farm animals genetic resources. Final report. Country Report for SoWAn-GR. Bucarest 2003; pp 56.

[56] Bachev H. Competitiveness in Bulgarian farms. MPRA Paper $\mathrm{N}^{\mathrm{o}}$ 25626. Munich 2010.

[57] Vicente-Serrano SM, Lasanta T, Romo A. Analysis of spatial and temporal evolution of vegetation cover in the Spanish central Pyrenees: Role of human management. Environ Manage 2004; 34 : 802-18.

[58] Burgi M, Hersperger AM, Schneeberger N. Driving forces of landscape change - current and new directions. Landscape Ecol 2004; 19: 857-68.

[59] Kleijn D, Kohler F, Baldi A, et al. On the relationship between farmland biodiversity and land-use intensity in Europe. P Roy Soc B-Sci 2009; 276: 903-9.

[60] Royal Society. Reaping the benefits: science and the sustainable intensification of global agriculture. Royal Society Policy Document 11/09. London 2009.

[61] Godfray C, Beddington JR, Crute IR, et al. Food security: the challenge to feeding 9 billion people. Science 2010; 327: 812-8.

[62] Pretty J, Toulmin C, Williams S. Sustainable intensification in African agriculture. Int J Sustain Agric 2011; 9(1), 5-24.

[63] Tittonell P, van Wijk MT, Herrero M, Rufino MC, de Ridder N, Giller KE. Beyond resource constraints-exploring the biophysical feasibility of options for the intensification of smallholder croplivestock systems in Vihiga district, Kenya. Agric Syst 2009; 101: $1-19$.

[64] Jansen J. Managing Natura 2000 in a changing world: the case of the Serra da Estrela. PhD Thesis. Radboud University, Nijmegen, The Netherlands 2011

[65] COM. Communication from the Commision on halting the loss of biodiversity by 2010 and beyond. COM216 final. Brussels 2006.

[66] Beaufoy G, Baldock D, Clark J. The nature of farming: lowintensity farming system in nine European countries. Institute for European Environmental Policy (IEEP). London 1994.

[67] Beaufoy G. Possibilities and future perspectives for Less favoured areas scheme support on high nature value farming. In: Report of workshop. EU Contract ENV.B.2/SER/2005/0037. Farming practices and the conservation of dry grasslands in the European Union. Madrid 2006; pp. 24-26.

[68] EEA. High nature value farmland. Characteristics, trends and policy challenges. European Environmental Agency. Report. No 1/2004. Copenhagen, Denmark 2004.

[69] IEEP. Guidance documents to Member States on the application of the HNV impact indicators. Institute for European Environmental Policy. London 2007b

[70] Beaufoy G, Caballero R, Oñate JJ. Spain. In: Oppermann R, Beaufoy G, Jones G, Eds. High Nature Value Farming in Europe. Verlag regional culture, Ubstadt-Weiger, Germany 2012; pp. 382405. 
[71] Beaufoy G, Keenleyside C, Oppermann R. How should EU and national policies support HNV farming? In: Oppermann R, Beaufoy G, Jones G, Eds. High Nature Value Farming in Europe. Verlag regionalculture, Ubstadt-Weiher, Germany 2012; pp. 52435.

[72] Nisbet A, Glaves DI. Moorland management in Higher Level Stewardship: the evidence base for sustainable stocking rates. Aspects Appl Biol 2010; 100: 141-9.
[73] Moreira BM (coord). Definitions and management alternatives to overcome the economic and ecological bottlenecks. WP5, Deliverable 5.5. LACOPE Contract EVK2-CT-2002-00150. Stuttgart, Germany 2004.

Received: July 17, 2014

Revised: December 11, 2014

Accepted: December 11, 2014

(C) Rafael Caballero; Licensee Bentham Open.

This is an open access article licensed under the terms of the Creative Commons Attribution Non-Commercial License (http://creativecommons.org/licenses/by-nc/3.0/) which permits unrestricted, non-commercial use, distribution and reproduction in any medium, provided the work is properly cited. 